\title{
Zooplankton of tidal marsh channels in relation to environmental variables in the upper San Francisco Estuary
}

\author{
Stephen M. Bollens ${ }^{1, *}$, Joanne K. Breckenridge ${ }^{1}$, Jeffery R. Cordell ${ }^{2}$, \\ Charles A. Simenstad ${ }^{2}$, Olga Kalata ${ }^{1,2}$
}

${ }^{1}$ School of the Environment, Washington State University, 14204 NE Salmon Creek Avenue, Vancouver, WA 98686-9600, USA ${ }^{2}$ School of Aquatic and Fishery Sciences, University of Washington, Seattle, WA 98105, USA

\begin{abstract}
Zooplankton are important trophic intermediaries between aquatic primary producers and higher level consumers such as fish, but to date they have been little studied in intertidal marshes. This is particularly true in the San Francisco Estuary (SFE), which is heavily impacted by human activities and is being targeted for restoration of its native wetland communities. As part of a multi-year field study investigating wetland dynamics in the upper SFE, we conducted approximately quarterly sampling of the mesozooplankton $(>73 \mu \mathrm{m})$ at 3 channels in each of 6 marshes. Here, we describe seasonal and regional variation in the composition and abundance of zooplankton, and relate these to variations in environmental conditions. Cluster analysis identified 6 different marsh zooplankton communities. The 66 taxa identified included both native and non-indigenous species (NIS), with NIS being particularly dominant in the summer and autumn. Ordination analyses indicated that salinity, temperature, and other freshwater-related variables such as freshwater flow and distance to the coastal ocean were the strongest environmental drivers of marsh zooplankton community composition and individual abundance. Zooplankton communities in intertidal marshes were similar to those of open water habitats of the SFE in many regards, although differences in some taxa were observed, e.g. higher abundances of the copepod Eurytemora affinis and lower abundances of tintinnid ciliates in the marshes. Apparent differences in zooplankton between intertidal marsh and open water habitats, and between different regions of the estuary, could have important implications for young fish and other consumers.
\end{abstract}

KEY WORDS: San Francisco Estuary - Non-indigenous species · Invasive copepods - Native species $\cdot$ Plankton

\section{INTRODUCTION}

Tidal marshes are highly productive ecosystems that provide important nursery and feeding habitats for fish and other aquatic organisms (Odum 1988, Kneib 1997, Beck et al. 2001, Minello et al. 2003, Allen et al. 2007). Zooplankton are critical trophic intermediaries between primary producers and higher level consumers, and as such play a central role in the flow of materials and energy through aquatic ecosystems. Despite this critical role, how-

${ }^{*}$ Corresponding author: sbollens@vancouver.wsu.edu ever, zooplankton communities in tidal marsh ecosystems have rarely been the focus of study (e.g. Houser \& Allen 1996, Mazumder et al. 2009, Zhou et al. 2009).

The upper part of the San Francisco Estuary (SFE), defined here as San Pablo Bay and all upstream areas under tidal influence, once had extensive marshes that appeared after the estuary was created by sea level rise. These marshes formed at the landward margin through a complex interaction of sediment and detritus accumulation, submergence and

() The authors 2014. Open Access under Creative Commons by Attribution Licence. Use, distribution and reproduction are unrestricted. Authors and original publication must be credited. 
sea level rise (Atwater et al. 1979). Beginning in the late 1800 s, these marshes were systematically drained, diked, and converted to farmland, such that the Sacramento-San Joaquin River Delta (hereafter referred to as the 'Delta') of the upper SFE now consists mainly of diked islands surrounded by deep channels. Subsequently, levees on a number of these islands have either failed, or were intentionally breached to restore tidal ecosystems, resulting in reconnection of the interior marshland to the surrounding channels. These, and the remaining predevelopment tidal marshes of the SFE have come under increasing scrutiny in recent years, coincident with declines in the abundance of native and common non-native nekton species, now commonly referred to as the 'Pelagic Organism Decline' (Sommer et al. 2007, Mac Nally et al. 2010). This has led to intensified interest in conservation and restoration of the SFE in general (Moyle 2008), and shallow water habitats specifically (Brown 2003, Lopez et al. 2006), although the exact relationship between shallow water habitat and pelagic organisms remains obscure.

The zooplankton of the open waters of the SFE have been reasonably well studied to date, both at the community level (Ambler et al. 1985, Kimmerer \& Orsi 1996, Bollens et al. 2002, 2011, Purkerson et al. 2003, Gewant \& Bollens 2005, Rollwagen-Bollens et al. 2006) and at the individual species level (Orsi \& Walter 1991, Rollwagen-Bollens \& Penry 2003, Hooff \& Bollens 2004, Bouley \& Kimmerer 2006, Ger et al. 2010, Gould \& Kimmerer 2010). However, the zooplankton communities of tidal marshes of the SFE have never been reported. Given that zooplankton are important prey items for many larval and adult fish in the SFE (Meng \& Orsi 1991, Moyle et al. 1992, Nobriga 2002, Bollens \& Sanders 2004, Visintainer et al. 2006, Cohen \& Bollens 2008, Howe et al. 2014, Whitley \& Bollens 2014), a need exists to investigate the basic ecology of tidal marsh zooplankton. More specifically, if the composition and abundance of zooplankton in tidal marshes are found to be suitable prey resources for fish and other higher-level consumers, this could provide a critical link between shallow water habitats (Brown 2003, Lopez et al. 2006) and conservation and restoration of pelagic species in the SFE (Sommer et al. 2007, Moyle 2008, Mac Nally et al. 2010).

Thus, the specific objectives of this study were to (1) describe the distribution, abundance, composition, and spatial distribution of tidal marsh mesozooplankton in the SFE, with special emphasis on non-indigenous copepods; (2) relate variation in the zooplankton communities to physical environmental variables (e.g. salinity, temperature, freshwater flow, etc.); and (3) compare these results to recent findings of open-water mesozooplankton in the SFE to examine possible differences between intertidal marshes and open water regions of the SFE.

\section{MATERIALS AND METHODS}

The SFE experiences a Mediterranean climate with most precipitation occurring between November and April. Most freshwater discharge occurs through the upper SFE and the Delta. Since 1850, the total area of marsh in the upper SFE has been reduced by reclamation to less than $6 \%$ of its original extent (Nichols et al. 1986).

As part of the Integrated Regional Wetland Monitoring (IRWM) project, 6 tidal marshes in the upper SFE (Fig. 1) were sampled over the 2004 and 2005 water years (WY) on an approximately quarterly basis (WY 2004: 25-28 October and 10-11 November 2003, 13-18 February, 14-19 June, and 26-30 September; WY 2005: 8-13 January, 26-31 March, and 19-24 June). During January 2005, September 2005 and June 2004 and 2005, marshes were sampled during darkness; sampling occurred during daylight on all other dates. Sampled marshes (listed in order of decreasing marine influence) were located on the Petaluma River (Carl's Marsh), Napa River (Pond 2A, Coon Island, and Bull Island), and in the western part of the Sacramento-San Joaquin River Delta, hereafter referred to as 'west Delta' (Browns Island and Sherman Lake). Dominant vegetation types varied between marshes, but amount of vegetation cover was comparable-approximately $75 \%$, with the exception of Carl's Marsh (59\%) (L. Shile \& K. Tuxin unpubl. data). For further site description see Howe \& Simenstad (2011) and Gewant \& Bollens (2012).

Mesozooplankton were collected using a $0.25 \mathrm{~m}$ diameter mouth, $73 \mu \mathrm{m}$ mesh plankton net from 3 tidal channels within each marsh, for a total of 18 sampled channels. At each channel, triplicate vertical hauls were collected from near bottom to the surface near the marsh edge at the beginning of ebb tide. Tow depth averaged $1.3 \mathrm{~m}$ and ranged between 0.2 and $3.0 \mathrm{~m}$. Volume filtered was calculated from tow depth and net mouth area. Temperature and salinity for each marsh were measured using a YSI ${ }^{\mathrm{TM}}$ 85. Salinity and temperature were compared between marshes and seasons (wet: November to May; dry: June to October) using 2-way ANOVAs. Samples from our first collection (which occurred in October and November 2003) were treated as dry 

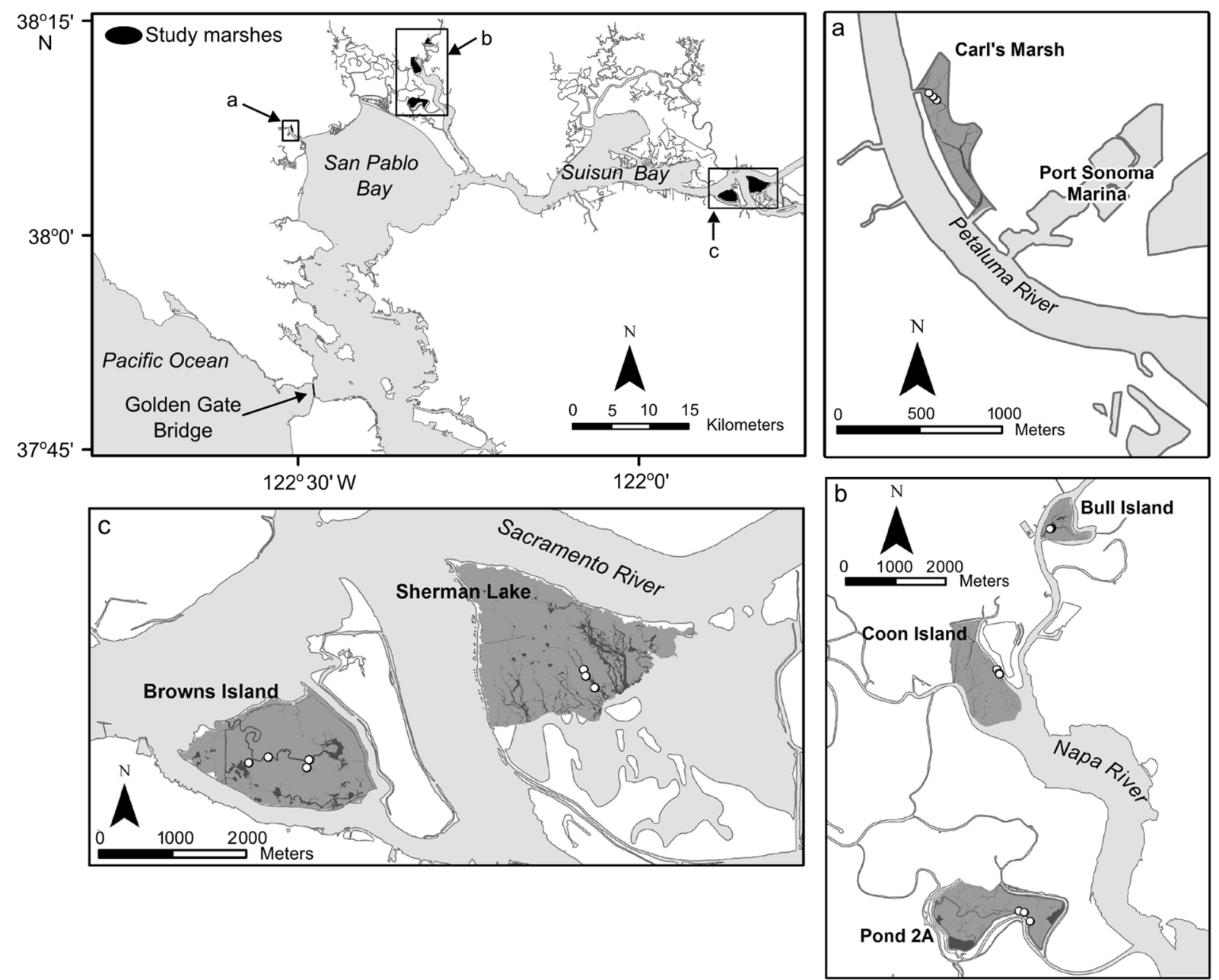

Fig. 1. Upper San Francisco Bay and Delta region; insets show sampled regions of (a) Petaluma River, (b) Napa River, and (c) west Sacramento-San Joaquin River Delta. The 3 channels sampled within each marsh are indicated by open circles. At Bull Island and Coon Island marshes, symbols indicating a sampling site overlap. At Browns Island, the location of a sampled channel changed, resulting in 4 rather than 3 sampling locations

season samples based on the hydrograph (see Fig. 2). Where data did not meet the assumptions of normality or equality of variance, a rank transformation was applied.

Collected specimens were identified and enumerated under a dissecting microscope. Where possible, and for all copepods, taxa were further sorted into juvenile or adult categories. For the first 3 quarterly sampling events (October/November 2003, February and June 2004), subsamples of triplicate samples from each channel were processed; for all subsequent collections, duplicate samples were processed in their entirety, resulting in species count data for 304 samples. A total of 159 taxa were identified, and abundances were calculated as ind. $\mathrm{m}^{-3}$ of filtered water.

To facilitate the interpretation and presentation of plankton data, benthic (e.g. nematodes, oligochaetes, anthozoans, hydrozoans, certain harpacticoids, amphipods, and insects etc.), and terrestrial (i.e. arachnids, entognaths, and most insects) species were omitted from the analyses. Here, we present analyses of $\log (x+1)$-transformed abundances of 66 plankton taxa in 304 samples, hereafter referred to as the 'species matrix'. One empty sample from Carl's Marsh in June 2005 and an outlier sample from Sherman Lake in February 2004 that contained only ostracods were also excluded. Rare taxa (present in fewer than 9 samples) were excluded from multivariate analyses. Due to extremely high abundances, copepod nauplii were also excluded from the analyzed species matrix. Instead, variation in copepod nauplii abundance was added to our environmental matrix (described below) and investigated through correlation to ordination axes. 
Samples representing similar mesozooplankton communities were grouped by a hierarchical, agglomerative cluster analysis using Sørensen (Bray-Curtis) distance and a flexible-beta linkage $(0.25)$ on $\log (x+1)$ species abundance data. Significant indicators of clusters were identified using Indicator Species Analysis (Dufrêne \& Legendre 1997) and a Bonferroni corrected alpha of 0.00045 . Due to a high number of significant indicators (44), we employed arbitrary cut-offs to identify the strongest indicator species based on indicator values (IV), similar to Keister \& Peterson (2003), and also on frequency of occurrence within a cluster. To be considered a strong indicator, the IV of the taxon must have been $3 \times$ greater than for other clusters, and indicator taxa must have been present in at minimum $90 \%$ of samples contained in the cluster.

Nonmetric multidimensional scaling (NMS) using the Sørensen distance measure was used to ordinate samples included in the species matrix and allowed us to relate variation in community composition to environmental variables. Variables included in a secondary environmental matrix and correlated to ordination axes salinity, temperature, distance to the Golden Gate bridge (which crosses the mouth of San Francisco Bay and was therefore used as a measure of distance to the coastal ocean and thus marine influence), Julian date, tow depth, and copepod nauplii abundance. Two continuous indices were calculated; one for season that contrasted February $1(-1)$ and August $1(+1)$, and one for time of day that contrasted midnight $(-1)$ and noon $(+1)$. To investigate the influence of river flow, river discharge data were obtained from the United States Geological Survey for Petaluma (http://waterdata.usgs.gov/ca/nwis/uv/ ?site_no=11459150) and Napa (http://waterdata.usgs. gov/usa/nwis/uv?site_no=11458000) river sites, and from the California Department of water resources for west Delta sites (www.water.ca.gov/dayflow/ output/index.cfm). These region-specific data were combined into 3 variables for discharge from the day prior, week prior, and month prior to sampling. Reliable discharge data were not available for the Petaluma River for the period of interest. Where data were available, however, Petaluma River discharge tracked that of the Napa River, albeit at a lower magnitude, so we estimated discharge volumes for the Petaluma River to be $25 \%$ of that recorded at the Napa River. All multivariate analyses were performed using PC-ORD v.5 (McCune \& Mefford 2006).

To further investigate the prevalence of nonindigenous species in tidal marshes of the SFE, we compared the proportion of individuals known to be non-indigenous between wet and dry seasons, and between the Petaluma River (Carl's Marsh), the Napa River (Pond 2A, Coon Island, and Bull Island) and the west Delta (Sherman Lake and Browns Island), using 2-way ANOVAs. Data were rank transformed to equalize variances. Univariate analyses were performed using R v.2.13.1

\section{RESULTS}

Our sampled WY differed with respect to pattern and magnitude of river outflow (Fig. 2). Based on observed run-off, the California Department of Water Resources classified discharge in WY 2004 as 'below normal' and 'dry' for the Sacramento River and the San Joaquin Valley, respectively (http://cdec.water. ca.gov/cgi-progs/iodir/wsihist). In contrast, the discharge of these rivers in WY 2005 was classified as 'above normal' and 'wet,' respectively. Salinity was higher during the dry season (ANOVA on ranks, $\left.F_{1,30}=48.9, \mathrm{p}<0.001\right)$, and differed between marshes (ANOVA on ranks, $F_{5,30}=23.3, \mathrm{p}<0.001$ ), influenced by proximity to marine influence and flow volume of the particular river (Fig. 2). Salinity was significantly lower at Sherman Lake and Brown Island marshes than at other marshes, and was significantly lower at Bull Island marsh than at Carl's Marsh. Temperature varied predictably between wet and dry seasons $\left(F_{1,35}=112.2, \mathrm{p}<0.001\right)$, but did not vary significantly between marshes (Fig. 2).

A cluster analysis dendrogram $(0.9 \%$ chaining, Fig. 3) most often placed samples from the same marsh and sampling events together, indicating a high degree of within-marsh similarity in community composition. Samples from Pond 2A and Coon Island (Napa River) marshes often clustered together, as did samples from Sherman Lake and Browns Island (West Delta) marshes. We chose to interpret the 6 highest-order clusters, and at this level all but one of the within-marsh replicates (a sample from Bull Island in March 2005) were assigned to the same cluster.

Cluster 1 samples were collected from low-salinity waters (Table 1). They separated from Clusters 2 and 3 based on the presence and abundance of the calanoid copepod Sinocalanus doerrii and the cladoceran Bosmina longirostris; the near absence (or presence in only a few samples) of the cyclopoid copepod Oithona davisae, the harpacticoid copepod Coullana canadensis, and the predatory calanoid Tortanus dextrilobatus; and the low abundance of the cyclopoid Limnoithona tetraspina. Cluster 1 was 
Fig. 2. Freshwater flow over the study period estimated by California Department of Water resources for (a) the Sacramento-San Joaquin Delta, and by the United Stated Geologic Survey for (b) the Napa River and (c) Petaluma River. Measured salinity $(\boldsymbol{\nabla})$ and temperature $(\bullet)$ for each marsh are plotted by sampling date in the panel of their respective rivers. $\mathrm{CM}=$ Carl's Marsh, $\mathrm{P} 2 \mathrm{~A}=$ Pond 2A, $\mathrm{CI}=$ Coon Island, $\mathrm{BuI}=$ Bull Island, BrI = Browns Island, $\mathrm{SL}=$ Sherman Lake. Dashed line divides the sampled water years (WY)

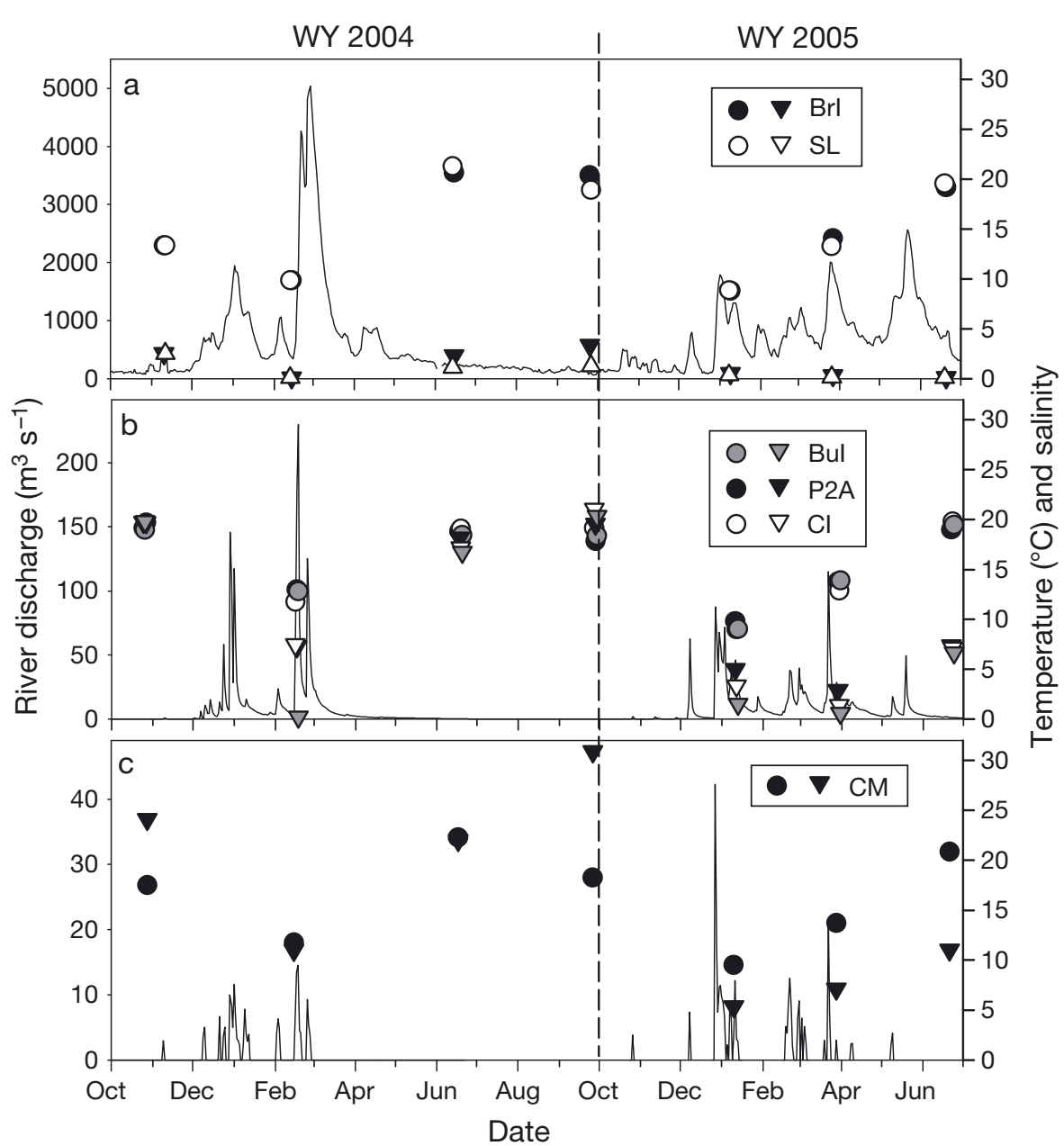

present at Bull Island and the west Delta marshes during the wet season (Table 2). Though occurring at similar salinity and temperatures, mesozooplankton communities in Cluster $1 \mathrm{a}$ and $1 \mathrm{~b}$ samples were quite distinct. Cluster 1a samples were dominated by either the calanoid Pseudodiaptomus forbesi, rotifers, or the calanoid Eurytemora affinis and indicated by $S$. doerrii. In contrast, Cluster 1b (Bull Island marsh in February 2004) represented a more freshwater community and was dominated by $B$. longirostris and the cyclopoid Diacyclops thomasi. Cluster 1b samples contained no L. tetraspina, no P. forbesi, and S. doerrii occurred in only 1 sample.

Lower abundances of $O$. davisae (by 1 to 3 orders of magnitude) separated Cluster 2 from Cluster 3. Cluster 2 samples were dominated by $L$. tetraspina but further divided into 2 subclusters based in each case upon the identity of the second most abundant copepod (Table 1). Cluster 2a was indicated by the presence of the calanoid Acartiella sinensis, had high abundances of $P$. forbesi, and was present in the west Delta during the dry season (Table 2). Cluster $2 b$ samples had high abundances of E. affinis and frequent presence of $D$. thomasi. Cluster $2 \mathrm{~b}$ was consistently present in the Petaluma and Napa Rivers during the wet season, and was present at Sherman Lake (West Delta) during the January 2005 sampling (Table 2).

Cluster 3 samples were collected from the more saline waters (Table 1) present during summer and autumn at Carl's Marsh (Petaluma River), and at Pond 2A, Coon Island, and Bull Island (Napa River). In November 2003 and September 2004, these sites were overwhelmingly dominated by O. davisae (Fig. 4). Cluster 3a samples contained high abundances of $L$. tetraspina and T. dextrilobatus. Cluster $3 \mathrm{~b}$ contained the calanoid Acartia californiensis, copepodids of Acartia spp. and poecilostomatid copepods of the family Clausidiidae. Cluster 3b was present at Carl's Marsh (Petaluma River) only in November 2003.

The NMS explained $86.3 \%$ of between-sample variation on 3 axes with a stress of 14.1. The primary axis explained $53.2 \%$ of this variation. Cluster 3 and Cluster 1 samples occurred on opposite ends of this 


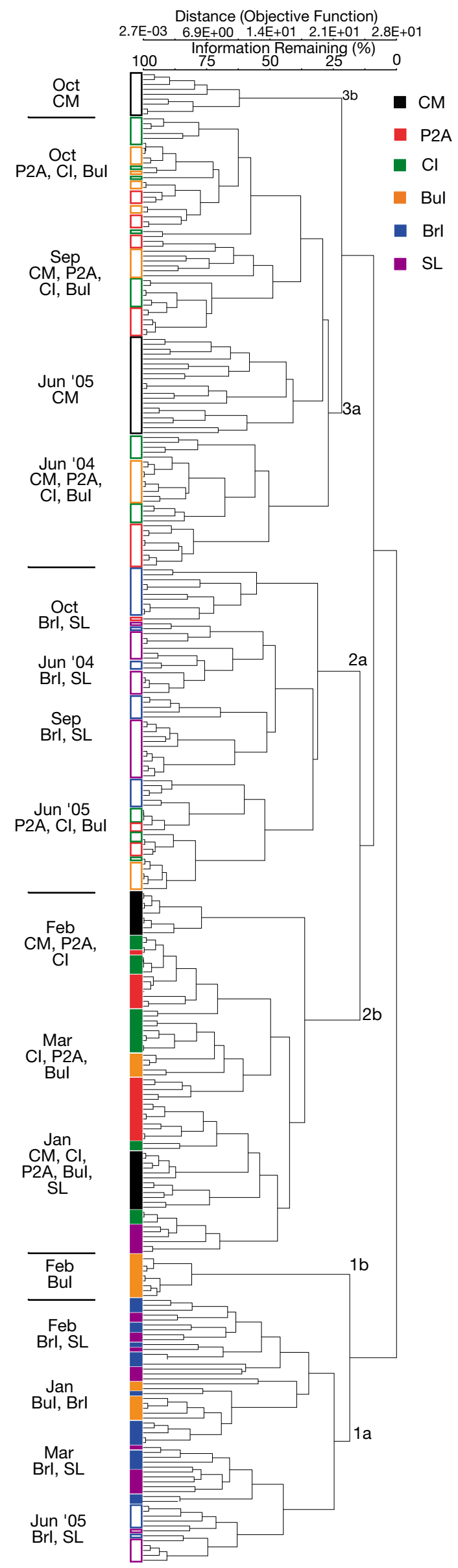

Fig. 3. Dendrogram of 304 mesozooplankton samples using Sørenson (Bray-Curtis) distance. Chaining 0.9\%. Labels indicate sampling event and marsh affiliations of samples included in each cluster. Colored bars further indicate marsh affiliation of samples. Open and closed bars represent dry and wet season samples, respectively. $\mathrm{CM}=$ Carl's Marsh, P2A = Pond 2A, CI = Coon Island, BuI = Bull Island, $\mathrm{BrI}=$ Browns Island, $\mathrm{SL}=$ Sherman Lake

axis, with Cluster 2 samples occurring in the middle (Fig. 5a). O. davisae, Clausidiidae copepodites, $T$. dextrilobatus, B. longirostris, S. doerrii, and A. californiensis varied strongly along this axis (Fig. 5b). This axis correlated strongly to variation in salinity ( $\mathrm{r}$ $=0.894)$, distance to Golden Gate $(r=-0.643)$, and river discharge from the previous day $(\mathrm{r}=-0.539)$, week $(\mathrm{r}=-0.566)$, and month $(\mathrm{r}=-0.577)$. For each cluster, subgroups 'a' and 'b' separated along Axis 2, which represented $18.5 \%$ of between-sample variation (Fig. 5a). Abundances of L. tetraspina, A. sinensis, $P$. forbesi, and to a lesser extent $B$. longirostris, $T$. dextrilobatus, and $E$. affinis varied along this axis (Fig. 5b). Axis 2 was correlated to our index of season, which contrasted warm and cool periods $(\mathrm{r}=$ $0.726)$, temperature $(r=-0.608)$, and time of day $(r=$ 0.625). Axis 3 (not shown) explained $14.6 \%$ of variation between samples and separated Clusters 3, 2, and $1 \mathrm{~b}$ from Cluster 1a. Polychaete larvae and $S$. doerrii abundance varied in opposite directions along this axis. Axis 3 was most strongly correlated to river flow averaged over the previous month $(\mathrm{r}=-0.595)$.

Copepod nauplii dominated the mesozooplankton community during our sampling events, followed by $O$. davisae and L. tetraspina (Table 3). Rotifers were also abundant and peaked during the wet season (Fig. 6). O. davisae dominated when salinities were high, with autumn average abundance exceeding 150000 ind. $\mathrm{m}^{-3}$ at Carl's Marsh (Petaluma River) (Figs. 4 \& 6). L. tetraspina was present year-round, dominating higher salinity marshes during the wet season and low salinity marshes during the dry season (Figs. 4 \& 6). E. affinis was present throughout the estuary when temperatures were cooler (Figs. 4 \& 7). P. forbesi was present primarily in the west Delta in June (Fig. 7). The abundance of T. dextrilobatus peaked in June of both years at Napa and Petaluma river marshes, with reduced abundances occurring in autumn (Fig. 7). Acartia spp. were most abundant at Carl's Marsh (Petaluma River). The proportion of the mesozooplankton community represented by non-indigenous individuals was greater 
Table 1. Average temperature, salinity, and time of collection for samples in each cluster and dominant taxa and indicator species. Standard deviation in parentheses. Both adult and juvenile stage included, except when noted. D: day, N: night

\begin{tabular}{|c|c|c|c|c|c|}
\hline Cluster & Temp. $\left({ }^{\circ} \mathrm{C}\right)$ & Salinity & $\mathrm{D} / \mathrm{N}$ & Dominant taxa & Indicator species \\
\hline $1 \mathrm{a}$ & $12.7(4.0)$ & $0.3(0.4)$ & $\mathrm{D}, \mathrm{N}$ & $\begin{array}{l}\text { Pseudodiaptomus forbesi, Rotifera, Ostracoda, } \\
\text { Eurytemora affinis, Sinocalanus doerrii }\end{array}$ & S. doerrii \\
\hline $1 b$ & $12.9(0.1)$ & $0.2(0)$ & $\mathrm{D}$ & $\begin{array}{l}\text { Bosmina longirostris, Diacyclops thomasi, } \\
\text { Daphnidae, Rotifera, Ostracoda }\end{array}$ & $\begin{array}{l}\text { Diaptomus franciscanus } \\
\text { (adult), Diaptomus spp., } \\
\text { B. longirostris, D. thomasi, } \\
\text { Daphnidae }\end{array}$ \\
\hline $2 \mathrm{a}$ & $18.2(3.1)$ & $3.5(2.3)$ & $\mathrm{D}, \mathrm{N}$ & $\begin{array}{l}\text { Limnoithona tetraspina, P. forbesi, Ostracoda, } \\
\text { Rotifera, Pseudobradya spp. }\end{array}$ & Acartiella sinensis \\
\hline $2 b$ & $11.6(1.8)$ & $5.2(3.3)$ & $\mathrm{D}, \mathrm{N}$ & $\begin{array}{l}\text { L. tetraspina, Rotifera, E. affinis, Ostracoda, } \\
\text { Acartia copepodites }\end{array}$ & E. affinis \\
\hline $3 a$ & $19.2(1.2)$ & $19.6(3.9)$ & $\mathrm{D}, \mathrm{N}$ & $\begin{array}{l}\text { Oithona davisae, L. tetraspina ,Gastropoda, } \\
\text { Spionodae, Ostracoda }\end{array}$ & Tortanus dextrilobatus \\
\hline $3 b$ & $17.5(0.2)$ & $24.1(0)$ & $\mathrm{D}$ & $\begin{array}{l}\text { O. davisae, Acartia californiensis, Polychaeta, } \\
\text { Acartia copepodites, Clausidiidae copepodites }\end{array}$ & $\begin{array}{l}\text { Clausidiidae copepodites, } \\
\text { Acartia copepodites, } \\
\text { A. californiensis }\end{array}$ \\
\hline
\end{tabular}

Table 2. Temporal distribution of mesozooplankton community clusters at six marshes in the upper San Francisco Estuary

\begin{tabular}{|c|c|c|c|c|c|c|c|}
\hline \multirow{2}{*}{ Site } & \multirow{2}{*}{$\begin{array}{c}2003 \\
\text { Oct }\end{array}$} & \multicolumn{3}{|c|}{2004} & \multicolumn{3}{|c|}{2005} \\
\hline & & Feb & Jun & Sep & Jan & Mar & Jun \\
\hline Carl's Marsh & $3 b$ & $2 b$ & $3 a$ & $3 a$ & $2 b$ & $2 b$ & $3 a$ \\
\hline Pond 2A & $3 a$ & $2 b$ & $3 a$ & $3 a$ & $2 \mathrm{~b}$ & $2 b$ & $2 a$ \\
\hline Coon Island & $3 a$ & $2 b$ & $3 a$ & $3 a$ & $2 b$ & $2 b$ & $2 \mathrm{a}$ \\
\hline Bull Island & $3 a$ & $1 \mathrm{~b}$ & $3 a$ & $3 a$ & $1 \mathrm{a}$ & $2 \mathrm{~b}$ & $2 a$ \\
\hline Browns Island & $2 \mathrm{a}$ & $1 \mathrm{a}$ & $2 \mathrm{a}$ & $2 \mathrm{a}$ & $1 \mathrm{a}$ & $1 \mathrm{a}$ & $1 \mathrm{a}$ \\
\hline Sherman Lake & $2 \mathrm{a}$ & $1 \mathrm{a}$ & $2 \mathrm{a}$ & $2 \mathrm{a}$ & $2 b$ & $1 \mathrm{a}$ & $1 \mathrm{a}$ \\
\hline
\end{tabular}

during the dry season than the wet season (ANOVA on ranks, $F_{1,120}=75.973, \mathrm{p}<0.001$ ), but our analysis did not detect a significant difference between rivers (Fig. 8).

\section{DISCUSSION}

Although ours is the first study to report on intertidal marsh zooplankton in the SFE, the dominant taxa we observed have been previously reported to occur in the open waters of the SFE (e.g. Ambler et al. 1985, Kimmerer \& Orsi 1996, Bollens et al. 2002, 2011, Purkerson et al. 2003, Hoof \& Bollens 2004). For instance, we observed a wide range of both native copepods (Diacyclops thomasi and Acartia spp.) and non-native copepods (Oithona davisae, Tortanus dextrilobatus, Sinocalanus doerrii, Limnoithona tetraspina, Acartiella sinensis, and Pseudodiaptomus forbesi) broadly distributed in the marshes. The member of the Eurytemora affinis species complex that is present in the SFE is also considered nonnative (Lee 2000). Cladocerans, rotifers and polychaete larvae were also widespread. These taxa were not uniformly distributed in time and space, but were associated with several different environmental variables.

Salinity was the strongest environmental driver of zooplankton community composition and individual abundance in intertidal marshes of the SFE. For instance, our NMS ordination of zooplankton communities revealed that salinity was the single strongest environmental correlate (Fig. 5a), along with other freshwater-related variables such as freshwater flows (averaged over various time periods) and distance to the Golden Gate (coastal ocean).

Inter-annual variability in salinity, driven by variable freshwater flows, was evident in the different cluster affiliations of Petaluma and west Delta marsh zooplankton between June 2004 and 2005. While temperature varied little and samples were consistently collected at high water, salinity was $~ 10$ lower for Napa and Petaluma River marshes in June 2005 than in June 2004, and 1.5 lower for west Delta marshes. The increased riverine influence and resulting lowered salinities in June 2005 coincided with reduced abundances of $O$. davisae in all sampled marshes and of L. tetraspina in west Delta marshes (Fig. 6). In contrast, the calanoid copepods P. forbesi and $A$. sinensis were particularly abundant in Napa River marshes in June 2005 (Fig. 7), although Napa River marshes remained affiliated with the same cluster due to consistently high abundances of $L$. tetraspina and T. dextrilobatus. 

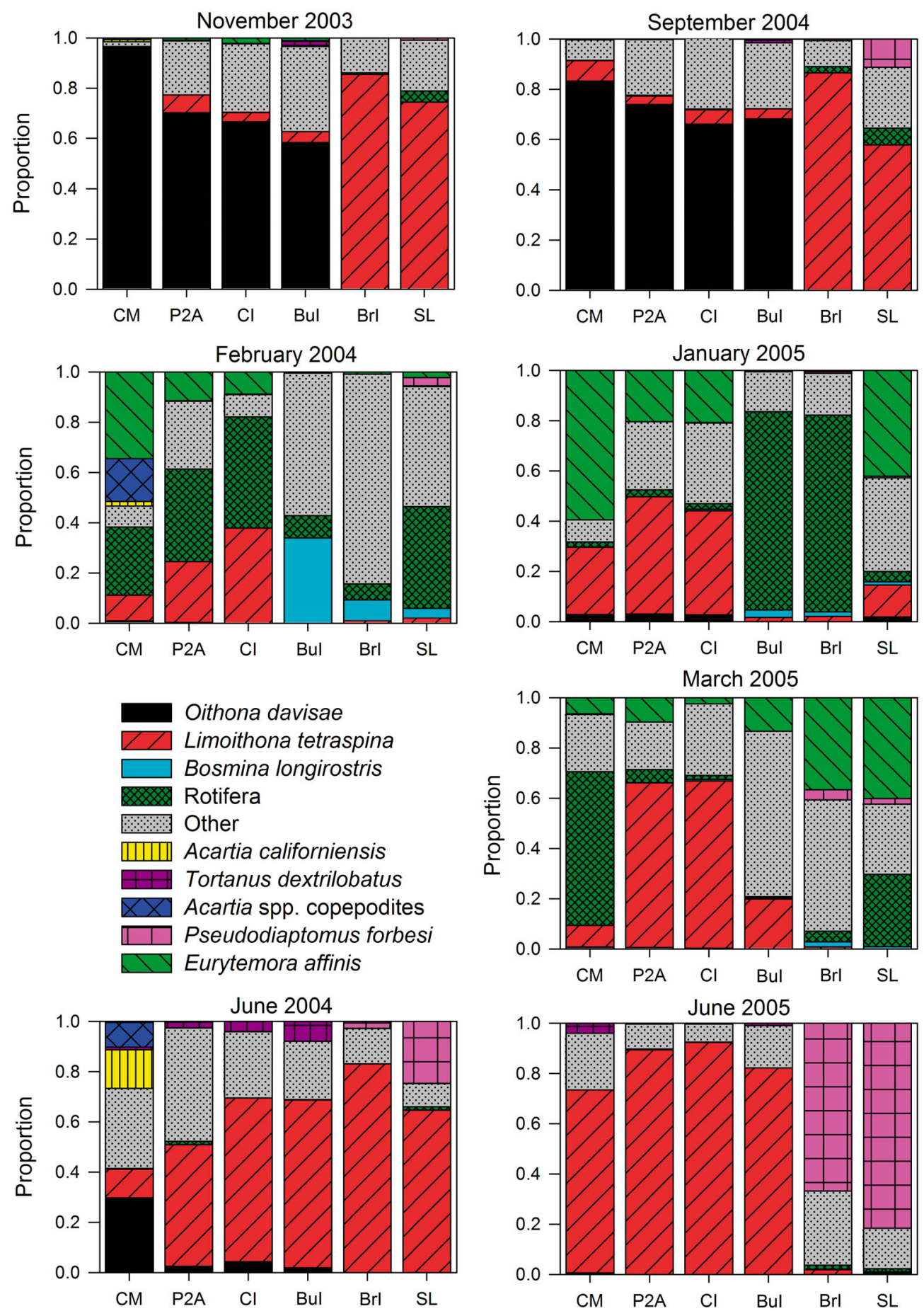

Fig. 4. Average proportional abundance of select taxa by marsh for each sampling event. CM= Carl's Marsh, P2A = Pond 2A, $\mathrm{CI}=$ Coon Island, BuI = Bull Island, BrI = Browns Island, $\mathrm{SL}=$ Sherman Lake

The importance of salinity in structuring estuarine zooplankton communities has been well established (e.g. Holt \& Strawn 1983, Soetaert \& Van Rijswijk 1993, Gewant \& Bollens 2005, Breckenridge et al. 2014), although most of these previous studies have emphasized open water habitats. Far fewer studies of intertidal marsh zooplankton have been reported. Houser \& Allen (1996) found salinity to affect the relative abundance of a wide variety of zooplankton taxa in Oyster Landing Creek, an intertidal basin in North Inlet Estuary, South Carolina, USA. Similarly, Zhou et al. (2009) found that salinity accounted for 


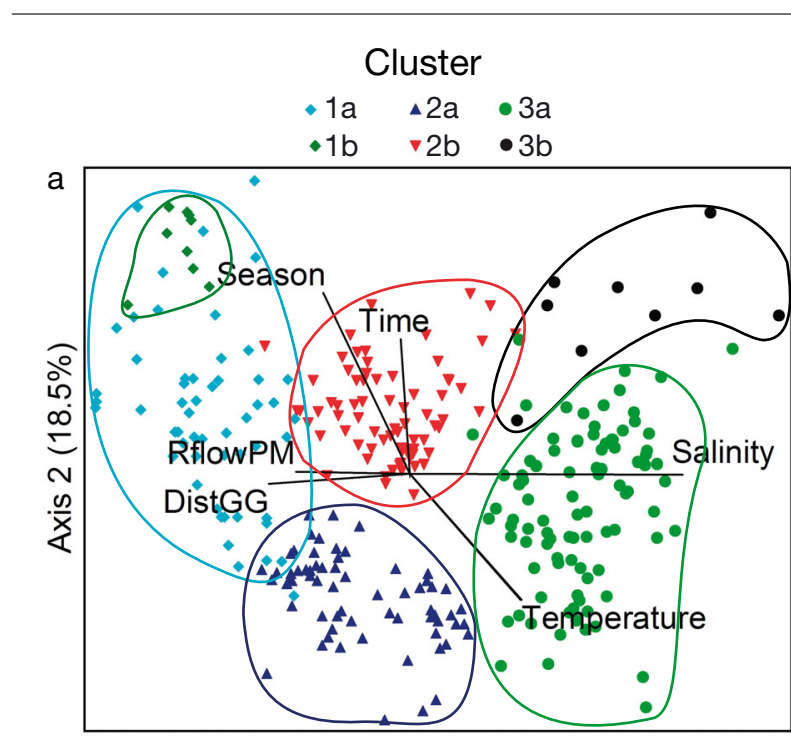

Axis $1(53.2 \%)$

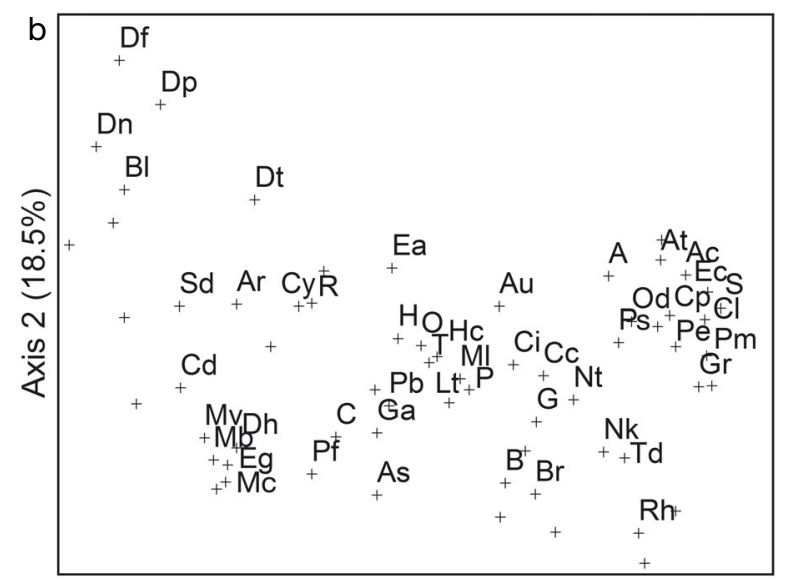

Axis $1(53.2 \%)$

Fig. 5. (a) Nonmetric multidimensional scaling (NMS) ordination of samples with cluster overlay. Circles are used to aid visualization of clusters and do not necessarily contain all samples within a cluster. Joint plot shows direction and relative strength of correlations of environmental variables to ordination axes. DistGG = distance to Golden Gate; RflowPM = average river discharge over previous month. Joint plot cut-off is $\mathrm{r}^{2}=0.33$. (b) NMS ordination plotting taxa scores as calculated by weighted averaging. Average position of included taxa along ordination axes is indicated by $(+)$. Most abundant 50 taxa are labeled. Sample points and joint plot not displayed but identical to (a). A = Acartia copepodites, $\mathrm{Ac}=\mathrm{A}$. californiensis, $\mathrm{Ar}=$ Acanthocyclops robustus, $\mathrm{As}=$ Acartiella sinensis, At $=$ Acartia tonsa, $\mathrm{Au}=$ Acartia (Acartiura) $\mathrm{spp} ., \mathrm{B}=$ Bivalvia, $\mathrm{Bl}=$ Bosmina longirostris, $\mathrm{Br}=$ Bryozoa, $\mathrm{C}=$ Cladocera, $\mathrm{Cc}=$ Coullana canadensis, $\mathrm{Cd}=$ Chydorid, $\mathrm{Ci}=$ Cirripedia nauplii, $\mathrm{Cl}=$ Clausidiidae, $\mathrm{Cp}=$ cyclopinid, $\mathrm{Cy}=\mathrm{Cy}-$ clopoid, $\mathrm{Df}=$ Diaptomus fran-ciscanus, $\mathrm{Dh}=$ Diaphanosoma spp., Dn = Daphnia spp., Dp = Diaptomidae, Dt = Diacyclops thomasi, Ea = Eurytemora affinis, $\mathrm{Ec}=$ Euterpina acutifrons, $\mathrm{Eg}=$ Eucyclops agilis, $\mathrm{G}=$ Gastropoda, $\mathrm{Ga}=$ Gammaridae, $\mathrm{Gr}=$ Grapsidae, $\mathrm{H}=$ Harpacticoid, $\mathrm{Hc}=$ Halicyclops sp., $\mathrm{Lt}=$ Limnoithona tetraspina, $\mathrm{Mb}=$ Macrocyclops albidus, $\mathrm{Mc}=$ Macrocyclops spp. copepodites, $\mathrm{Ml}=$ Microarthridion littorale, $\mathrm{Mv}=$ Microcyclops varicans, $\mathrm{Nk}=$ Neomysis kadiakensis, $\mathrm{Nt}=$ Neotachidius triangularis, $\mathrm{O}=$ Ostracoda, $\mathrm{Od}=$ Oithona davisae, $\mathrm{P}=$ Polychaeta, $\mathrm{Pb}=$ Pseudobradya spp., $\mathrm{Pe}=$ Pseudodiaptomus euryhalinus, $\mathrm{Pf}=P$. forbesi, $\mathrm{Pm}=P$. marinus, $\mathrm{Ps}=$ Pseudodiaptomus copepodites, $\mathrm{R}=$ Rotifera, $\mathrm{Rh}=$ Rhithropanopeus, $\mathrm{S}=$ Spionidae, $\mathrm{Sd}=$ Sinocalanus doerri, $\mathrm{T}=$ Tachidiidae, and $\mathrm{Td}=$ Tortanus dextrilobatus most of the spatial variation of zooplankton communities in several intertidal creeks within the Dongtan marshes of the Yangtze River Estuary, China. Thus, our results on intertidal marsh zooplankton, while the first of their kind for the SFE, are consistent with previous studies of estuarine zooplankton showing the central role of salinity.

Temperature and season were also relatively strongly correlated with variation in SFE marsh zooplankton, as has been found previously for open waters of the SFE (Bollens et al. 2011) as well as for other estuaries (Soetaert \& Van Rijswijk 1993, Marques et al. 2006, Graham \& Bollens 2010). Along with salinity, water column temperature has been used to predict the presence of a copepod species in an estuary within its geographical range (Cordell et al. 2010). Temperature can affect zooplankton both directly, via physiological tolerances and individual rate processes (e.g. respiration, growth, etc.), and indirectly, via cascading temperature-dependent rates of predator-prey dynamics. And of course, 'season' encompasses variation in a wide range of environmental conditions, both biotic and abiotic, and is a defining characteristic of most temperate ecosystems. For instance, salinity is itself a highly seasonally variable in a Mediterranean climate like that of the SFE, where there are clear and pronounced 'dry' and 'wet' seasons reflected in variable freshwater flows (e.g. Fig. 2).

One particularly noteworthy and interesting aspect of this seasonality in the SFE concerns invasive species. The prevalence of invasive species in the zooplankton assemblage of the SFE is well documented (see Bollens et al. 2011 and references therein, Cordell 2012). For the marsh zooplankton reported here, we found a striking seasonality to this patterndominance by invasive species of zooplankton is greater in summer/autumn than in winter/spring (Fig. 8). A similar pattern can be seen in data from the Interagency Ecological Program (IEP), which has conducted monthly monitoring of the open water zooplankton in the upper SFE since 1972, with current stations ranging from San Pablo Bay east to the lower Sacramento and San Joaquin rivers (www.dfg.ca.gov/delta/projects.asp?ProjectID=ZOO PLANKTON). Though the gear used for IEP collections $(160 \mu \mathrm{m}$ mesh Clarke-Bumpus net and pump samples filtered through $35 \mu \mathrm{m}$ mesh net) differed from that used in our study, a similar seasonal pattern of greater dominance by non-native taxa in summer months is evident in the IEP data. Indeed, this same pattern was also found recently in the Columbia River Estuary (Bollens et al. 2012). 
Table 3. Average abundance (ind. $\mathrm{m}^{-3}$ ), standard error (SE) and frequency of occurrence (\%) of the 50 most abundant taxa collected

\begin{tabular}{|c|c|c|c|c|}
\hline & Taxon & $\begin{array}{l}\text { Average } \\
\text { abundance }\end{array}$ & SE & $\begin{array}{l}\text { Frequency } \\
\qquad(\%)\end{array}$ \\
\hline Copepoda & Copepod nauplii & 18437.8 & 1373.1 & 100.0 \\
\hline \multicolumn{5}{|l|}{ Copepoda: } \\
\hline \multirow{15}{*}{ Calanoida } & Eurytemora affinis & 969.4 & 161.8 & 56.9 \\
\hline & Pseudodiaptomus forbesi & 771.7 & 159.9 & 37.5 \\
\hline & $\begin{array}{l}\text { Pseudodiaptomus forbesi } \\
\text { nauplii }\end{array}$ & 770.3 & 292.7 & 6.3 \\
\hline & Acartia copepodites & 328.3 & 96.5 & 20.1 \\
\hline & Acartia californiensis & 308.6 & 130.7 & 17.4 \\
\hline & Tortanus dextrilobatus & 164.6 & 23.8 & 37.8 \\
\hline & Acartiella sinensis & 150.3 & 40.2 & 31.9 \\
\hline & Acartia (Acartiura) spp. & 77.3 & 26.2 & 16.8 \\
\hline & $\begin{array}{l}\text { Pseudodiaptomus spp. } \\
\text { copepodites }\end{array}$ & 42.8 & 9.7 & 20.1 \\
\hline & Sinocalanus doerrii & 42.2 & 9.2 & 24.0 \\
\hline & $\begin{array}{l}\text { Pseudodiaptomus } \\
\text { euryhalinus }\end{array}$ & 40.3 & 8.0 & 16.8 \\
\hline & $\begin{array}{l}\text { Pseudodiaptomus } \\
\text { marinus }\end{array}$ & 13.2 & 51.6 & 11.5 \\
\hline & Diaptomus spp. & 8.6 & 47.4 & 7.2 \\
\hline & $\begin{array}{l}\text { Diaptomus franciscanus } \\
\text { adults }\end{array}$ & 6.2 & 2.0 & 4.9 \\
\hline & Acartia tonsa & 6.1 & 3.8 & 3.6 \\
\hline \multicolumn{5}{|l|}{ Copepoda: } \\
\hline \multirow[t]{11}{*}{ Cyclopoida } & Oithona davisae & 12330.1 & 3033.2 & 51.0 \\
\hline & Limnoithona tetraspina & 11334.6 & 1135.9 & 85.9 \\
\hline & Cyclopoida & 166.3 & 59.0 & 52.6 \\
\hline & Diacyclops thomasi & 75.4 & 20.9 & 26.6 \\
\hline & Cyclopinidae & 59.8 & 21.2 & 12.5 \\
\hline & Acanthocyclops robustus & 53.1 & 15.6 & 29.9 \\
\hline & $\begin{array}{l}\text { Microcyclops varicans } \\
\text { rubellus }\end{array}$ & 26.1 & 19.9 & 8.9 \\
\hline & $\begin{array}{l}\text { Macrocyclops spp. } \\
\text { copepodites }\end{array}$ & 19.4 & 9.3 & 8.6 \\
\hline & Eucyclops agilis & 11.0 & 82.8 & 8.2 \\
\hline & Halicyclops spp. adults & 8.9 & 56.8 & 9.2 \\
\hline & $\begin{array}{l}\text { Macrocyclops albidus } \\
\text { adults }\end{array}$ & 8.0 & 3.2 & 9.2 \\
\hline \multicolumn{5}{|l|}{ Copepoda: } \\
\hline \multirow[t]{6}{*}{ Harpacticoida } & Pseudobradya spp. & 207.6 & 21.6 & 68.8 \\
\hline & Coullana canadensis & 122.3 & 12.3 & 56.9 \\
\hline & Harpacticoida & 30.2 & 5.1 & 35.2 \\
\hline & Tachidiidae & 18.6 & 4.2 & 19.1 \\
\hline & Euterpina acutifrons & 8.7 & 52.5 & 5.9 \\
\hline & $\begin{array}{l}\text { Neotachidius triangularis } \\
\text { adults }\end{array}$ & 7.6 & 2.1 & 9.5 \\
\hline \multicolumn{5}{|l|}{ Copepoda: } \\
\hline Poecilostomatoida & Clausidiidae copepodites & 62.8 & 12.8 & 22.4 \\
\hline Cirripedia & Cirripedia nauplii & 178.3 & 22.8 & 48.7 \\
\hline \multirow[t]{4}{*}{ Cladocera } & Bosmina longirostris & 80.8 & 23.2 & 23.0 \\
\hline & Daphnidae & 29.7 & 9.1 & 12.2 \\
\hline & Chydoridae & 25.9 & 7.5 & 18.4 \\
\hline & Cladocera & 15.3 & 107.8 & 6.3 \\
\hline Amphipoda & Gammaridae & 73.4 & 19.0 & 40.1 \\
\hline Mysida & Neomysis kadiakensis & 56.4 & 15.0 & 20.4 \\
\hline \multirow[t]{2}{*}{ Decapoda } & Rhithropanopeus harrisii & 25.1 & 8.7 & 8.6 \\
\hline & Grapsidae & 11.4 & 75.4 & 5.6 \\
\hline Ostracoda & Ostracoda & 1476.1 & 344.5 & 90.8 \\
\hline Rotifera & Rotifera & 1532.6 & 249.1 & 62.5 \\
\hline Bivalvia & Bivalvia & 54.3 & 11.7 & 21.7 \\
\hline Gastropoda & Gastropoda & 1012.4 & 236.4 & 50.7 \\
\hline \multirow{2}{*}{ Polychaeta } & Polychaeta & 758.3 & 136.9 & 57.2 \\
\hline & Spionidae larvae & 725.9 & 177.8 & 12.5 \\
\hline Bryozoa & Bryozoa larvae & 11.5 & 54.2 & 9.5 \\
\hline
\end{tabular}

The exact cause(s) of this pattern of seasonal dominance by invasive species is unknown. It could be due to greater physiological tolerance of higher temperatures and higher salinities by invaders, or due to inter-specific trophic interactions modulated by competition and predation. These are questions that warrant further research. Interestingly, this same pattern of summer dominance by invasive species has been previously noted for fish assemblages in the freshwater delta (Grimaldo et al. 2004) as well as the brackish intertidal marshes of the SFE (Gewant \& Bollens 2012). Moreover, we note that several of the invasive copepods present in this study have also invaded the Columbia River Estuary (Cordell et al. 2008, Bollens et al. 2012, Emerson et al. 2014); thus, the implications of these invasions are far-ranging, and need to be better understood.

It is important to note that in this study, the investigation of season was somewhat confounded by whether sampling occurred during night or day (although our consistent use of total water column sampling via vertical net hauls should have dampened any diel differences). Time of day was a strong correlate of axis 2, along with season and temperature. Both night and day communities were represented in our autumn and winter/early spring sampling events. These samples clustered together, indicating that seasonal effects were the stronger influence on community composition. For both of our June sampling events, however, sampling occurred only during darkness, so we cannot distinguish between seasonal and diel effects, such as diel vertical migration, which has been observed for some (but not all) SFE zooplankton taxa (Lougee et al. 2002, Rollwagen-Bollens et al. 2006).

One obvious question that arises is how our results from intertidal 

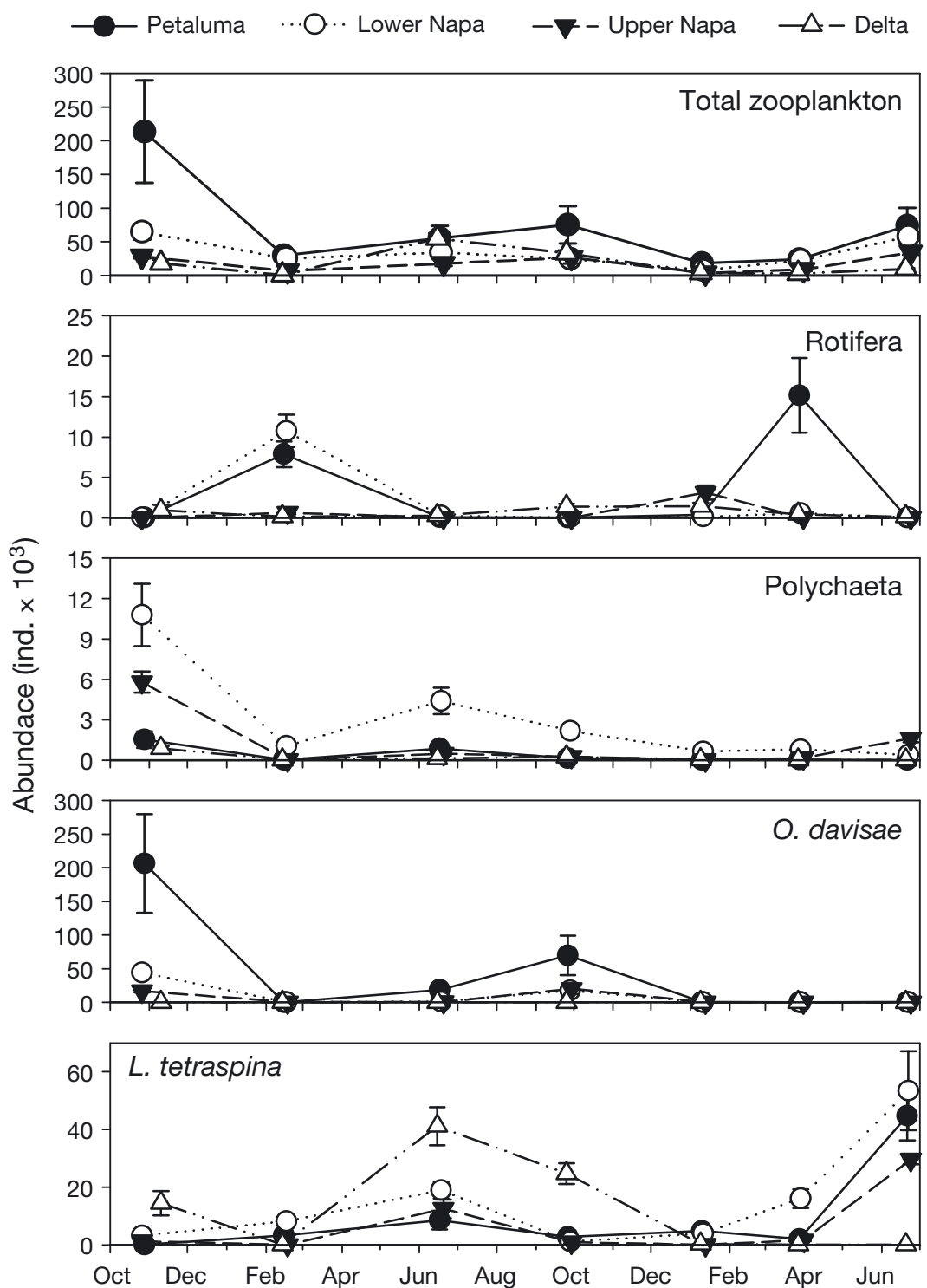

Fig. 6. Abundance $( \pm 1 \mathrm{SE})$ of total zooplankton, Rotifera, Polychaeta, Oithona davisae, and Limnoithona tetraspina, by sampling date and region. Petaluma $=$ Carl's Marsh, Lower Napa = Pond 2A and Coon Island, Upper Napa $=$ Bull Island, Delta $=$ Browns Island and Sherman Lake

marshes compare with those of recent open water sampling in the SFE. Several IEP stations are located in channel waters surrounding our sampling locations in the west Delta marshes. Graphical comparison of the zooplankton from our marsh samples and IEP samples showed that species compositions were very similar, and subsequent analysis using PERMANOVA (Anderson 2001) verified that there were no significant differences between our marsh and IEP open water stations in the west Delta (Browns Island and Sherman Lake). The high degree of similarity between west Delta marsh communities and the community in nearby open waters suggests that the marsh zooplankton community is an extension of that found in surrounding open waters.

Comparisons between our data from Napa and Petaluma river marshes and IEP open water stations were also made, but should be interpreted with even greater caution due to relatively large distances between our marsh sites and the IEP stations. We compared Napa and Petaluma river marsh zooplankton to IEP samples of similar salinity (San Pablo and Carquinez Strait during the dry season and Suisun and Grizzly Bays during the wet season). In autumn, Napa River marsh communities had a higher proportion of $O$. davisae compared to open water, where dominance was more evenly shared between $O$. davisae and $L$. tetraspina. Calanoid copepod taxa varied much more between locations than did cyclopoid copepod taxa, but Napa River marshes often had higher proportions of Diaptomid copepods and Tortanus spp. (particularly copepodites) than did open waters.

Our results from the Petaluma River (Carl's Marsh) were compared to IEP results from San Pablo Bay and Carquinez Strait stations. We also compared our Carl's Marsh results to those of Bollens et al. (2011), who sampled mesozooplankton from nearby San Pablo Bay using identical collection methods ( $73 \mu \mathrm{m}$, vertical hauls) as in the current study, as well as having the same individual responsible for specimen identification. Carl's Marsh had higher abundances of calanoid copepods than did the open water IEP stations. In February 2004 and January 2005, Carl's Marsh (Petaluma River) was dominated by $E$. affinis, which was not as abundant at the IEP open water sites. E. affinis was also much less abundant at comparable salinities in San Pablo Bay in the Bollens et al. (2011) study. Given the similarity between west Delta marsh and open water zooplankton noted above, these observed differences between Napa River and Petaluma River marsh zooplankton and open water zooplankton might represent a difference between river systems, rather than a difference between marsh and open 

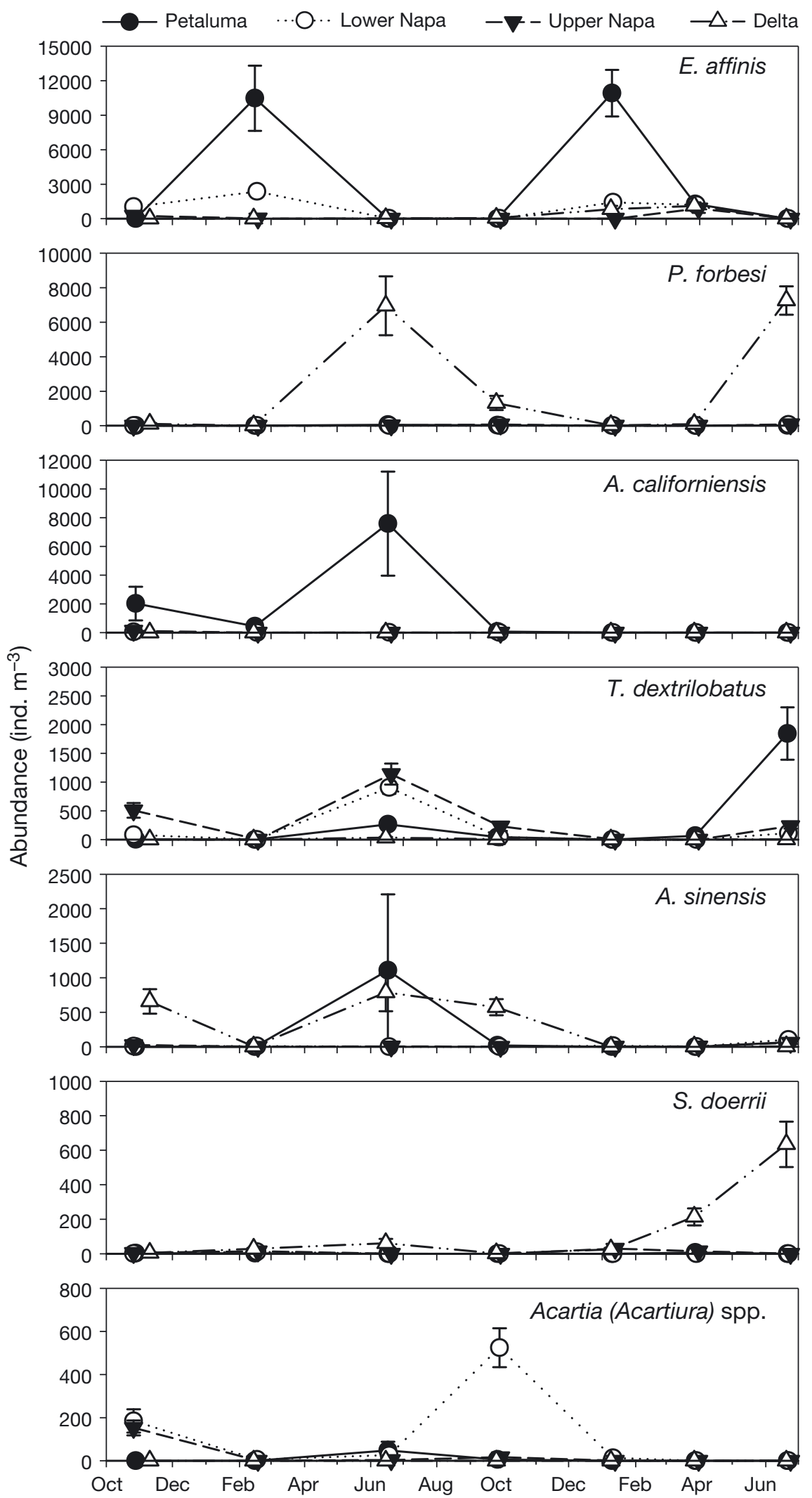

Fig. 7. Abundance $( \pm 1 \mathrm{SE})$ of select calanoid copepod taxa by sampling date and region. Petaluma $=$ Carl's Marsh, Lower Napa $=$ Pond 2A and Coon Island, Upper Napa = Bull Island, Delta = Browns Island and Sherman Lake 


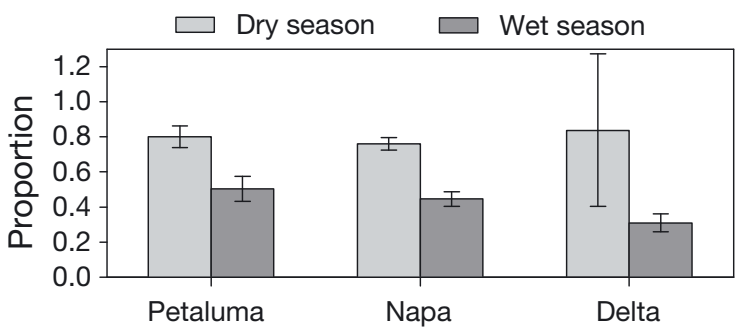

Fig. 8. Average proportion of sampled zooplankton ( $\pm 1 \mathrm{SE})$ known to be non-native by region and season (dry season = June to October; wet season = November to May)

water systems more generally. This may suggest that the lower reaches of rivers emptying into the SFE may support different zooplankton communities and, while salinity and temperature are important determinants of zooplankton community composition in the SFE overall, other regional factors may have a significant but still undetermined role.

Another important difference between intertidal marshes and open waters is that tintinnid ciliates were rare (always $<2000$ ind. $\mathrm{m}^{-3}$ ) in our study, compared to $>20000$ ind. $\mathrm{m}^{-3}$ reported by Bollens et al. (2011) for open waters of the SFE (note that both studies used the same collection techniques). Protists such as tintinnid ciliates can be important sources of food for larval fishes, both directly (Bollens \& Sanders 2004, Friedenberg et al. 2012) and indirectly via the microbial food web (Gifford et al. 2007, RollwagenBollens et al. 2011). Although we do not know whether the difference in tintinnid ciliate abundance between our study and Bollens et al. (2011) is due to interannual or habitat-specific differences, the low number of tintinnids present in marshes during our study may have implications for feeding and growth of young fish and other consumers, as well as cycling of material and energy in the estuary more generally.

Our study did not examine fluxes of zooplankton between marshes and open water in the SFE, but such studies are strongly recommended for the future. For instance, Houser \& Allen (1996) examined zooplankton fluxes in a South Carolina intertidal basin and found large pulses of crab and shrimp larvae exited but did not return to the intertidal basin, whereas postlarval decapods were more abundant on flood tides, indicating settlement and recruitment to the intertidal basin. Dean et al. (2005) examined the flux of the mysid Neomysis kadiakensis between a salt marsh and open water in the SFE and found the marsh to be a net sink of mysids. Likewise, Mazumder et al. (2009) examined the fluxes of various taxa between salt marsh and open water habitats in Towra Point, New South Wales, Australia and found the saltmarsh to be a net exporter of crab and gastropod larvae, and a sink for copepods and amphipods. Zooplankton flux studies such as these are essential to understanding the interactions between intertidal marshes and open water habitats of estuaries.

In summary, zooplankton communities in intertidal marshes and open water habitats of the SFE appear to be similar in many regards, including the strong effects of salinity, temperature, season, and invasive species. Yet we also observed some interesting differences in some taxa between these 2 habitats, e.g. the apparently higher abundances of $E$. affinis and lower abundances of tintinnid ciliates in the marshes (although again, such comparisons are complicated by the use of different samplers over different collection periods). These apparent differences in zooplankton, whether between intertidal marsh and open water habitats or between the lower reaches of different rivers, could have important implications for young fish and other consumers in the estuary. For instance, those fishes that prefer E. affinis as prey may grow and recruit at greater rates in the marshes compared with open waters, whereas those fishes that prefer tintinnid ciliates as prey may experience greater growth and recruitment in open water habitats. More generally, zooplankton composition and abundance may be a critical link between shallow water habitats (Brown 2003, Lopez et al. 2006) and conservation and restoration of pelagic species in the SFE (Sommer et al. 2007, Moyle 2008, Mac Nally et al. 2010). A more complete understanding of the dynamics of both intertidal marsh and open water systems, and the fluxes between the two, should be a high priority for future research in the SFE, especially in light of the increasing interest in managing and restoring this heavily impacted estuarine ecosystem.

Acknowledgements. We thank S. Avent, S. Cohen, K. Papastephanou, S. Gifford, and A. Dean, and staff and students of the University of Washington Wetland Ecosystems Team for their assistance in the field, and D. Morgan and D. Bell for boat operations. We greatly appreciate the assistance of April Hennessy, California Department of Fish and Game, in providing access to IEP zooplankton data. Funding for this study was provided by the Bay-Delta CALFED Program to S.M.B.

\section{LITERATURE CITED}

Allen DM, Haertel-Borer SS, Milan BJ, Bushek D, Dame RF (2007) Geomorphological determinants of nekton use of intertidal salt marsh creeks. Mar Ecol Prog Ser 329:57-71

Ambler JW, Cloern JE, Hutchinson A (1985) Seasonal cycles of zooplankton from San Francisco Bay. Hydrobiologia 129:177-197 
Anderson MJ (2001) A new method of non-parametric multivariate analysis of variance. Austral Ecol 26:32-46

Atwater BF, Conard SG, Dowden JN, Hedel CW, MacDonald RL, Savage W (1979) History, landforms, and vegetation of the estuary's tidal marshes. In: Conomos TJ (ed) San Francisco Bay: the urbanized estuary. Pacif Div Am Assoc Adv Sci, San Francisco, CA, p 347-385

> Beck MW, Heck KL Jr, Able KW, Childers DL and others (2001) The identification, conservation, and management of estuarine and marine nurseries for fish and invertebrates. Bioscience 51:633-640

Bollens SM, Sanders A (2004) Ecology of larval Pacific herring Clupea pallasi in the San Francisco Estuary: seasonal and interannual abundance, distribution, diet and condition. Am Fish Soc Symp 36:15-35

> Bollens SM, Cordell JR, Avent S, Hooff R (2002) Zooplankton invasions: a brief review, plus two case studies from the northeast Pacific Ocean. Hydrobiologia 480:87-110

Bollens SM, Breckenridge JK, Vanden Hooff RC, Cordell JR (2011) Mesozooplankton of the lower San Francisco Estuary: spatio-temporal patterns, ENSO effects, and the prevalence of non-indigenous species. J Plankton Res 33: 1358-1377

Bollens SM, Breckenridge JK, Cordell JR, RollwagenBollens GC, Kalata O (2012) Invasive copepods in the lower Columbia River Estuary: seasonal abundance, cooccurrence and potential competition with native copepods. Aquat Inv 7:101-109

Bouley P, Kimmerer WJ (2006) Ecology of a highly abundant, introduced cyclopoid copepod in a temperate estuary. Mar Ecol Prog Ser 324:219-228

Breckenridge J, Bollens SM, Rollwagen-Bollens GC, Roegner C (2014) Plankton assemblage variability in a riverdominated temperate estuary during late spring (highflow) and late summer (low-flow) periods. Estuar Coast, doi:10.1007/s12237-014-09820-7

Brown LR (2003) Will tidal wetland restoration enhance populations of native fishes? S Francisco Estuar Watershed Sci 1:1-42, https://escholarship.org/uc/item/2cp4d8wk

> Cohen S, Bollens SM (2008) Diet and growth of non-native Mississippi silversides and yellowfin gobies in restored and natural wetlands in the San Francisco Estuary. Mar Ecol Prog Ser 368:241-254

Cordell JR (2012) Invasive copepods of North America. In: Francis RA (ed) A handbook of global freshwater invasive species. Earthscan/Routledge, London, p 161-172

> Cordell JR, Bollens SM, Draheim R, Sytsma M (2008) Asian copepods on the move: recent invasions in the ColumbiaSnake River system, USA. ICES J Mar Sci 65:753-758

Cordell JR, Tear LM, Bollens SM (2010) Modelling physicochemical factors affecting occurrences of a non-indigenous planktonic copepod in northeast Pacific estuaries. Biol Invasions 12:1427-1445

Dean AF, Bollens SM, Simenstad C, Cordell JR (2005) Marshes as sources or sinks of an estuarine mysid: demographic patterns and tidal flux of Neomysis kadiakensis at China Camp Marsh, San Francisco Estuary. Estuar Coast Shelf Sci 63:1-11

Dufrêne M, Legendre P (1997) Species assemblages and indicator species: the need for a flexible asymmetrical approach. Ecol Monogr 67:345-366

Emerson JE, Bollens SM, Counihan T (2014) Seasonal dynamics of zooplankton in Columbia-Snake River system reservoirs, with special reference to the invasive copepod Pseudodiaptomus forbesi. Aquatic Invasions (in press)
Friedenberg L, Bollens SM, Rollwagen-Bollens G (2012) Feeding dynamics of larval Pacific herring (Clupea pallasi) on natural prey assemblages: the importance of protists. Fish Oceanogr 21:95-108

> Ger KA, Arneson P, Goldman CR, Teh SJ (2010) Species specific differences in the ingestion of Microcystis cells by the calanoid copepods Eurytemora affinis and Pseudodiaptomus forbesi. J Plankton Res 32:1479-1484

> Gewant DS, Bollens SM (2005) Macrozooplankton and micronekton of the lower San Francisco Estuary: seasonal, interannual and regional variation in relation to environmental conditions. Estuaries 28:473-485

Gewant DS, Bollens SM (2012) Fish assemblages of interior tidal marsh channels in relation to environmental variables in the upper San Francisco Estuary. Environ Biol Fishes 94:483-499

Gifford SM, Rollwagen-Bollens G, Bollens SM (2007) Mesozooplankton omnivory in the upper San Francisco Estuary. Mar Ecol Prog Ser 348:33-46

> Gould AL, Kimmerer WJ (2010) Development, growth, and reproduction of the cyclopoid copepod Limnoithona tetraspina in the upper San Francisco Estuary. Mar Ecol Prog Ser 412:163-177

Graham ES, Bollens SM (2010) Macrozooplankton community dynamics in relation to environmental variables in Willapa Bay, Washington, USA. Estuaries Coasts 33: 182-194

Grimaldo LF, Miller RE, Peregrin CM, Hymanson ZP (2004) Spatial and temporal distribution of native and alien ichthyoplankton in three habitat types of the Sacramento-San Joaquin Delta. In: Feyrer F, Brown LR, Brown RL, Orsi JJ (eds) Early life history of fishes in the San Francisco Estuary and watershed. Am Fish Soc Symp 39: 81-96

Holt J, Strawn KS (1983) Community structure of macrozooplankton in Trinity and Upper Galveston Bays. Estuaries 6:66-75

> Hooff RC, Bollens SM (2004) Functional response and potential predatory impact of Tortanus dextrilobatus, a recently introduced carnivorous copepod in the San Francisco Estuary. Mar Ecol Prog Ser 277:167-179

Houser DS, Allen DM (1996) Zooplankton dynamics in an intertidal salt-marsh basin. Estuaries 19:659-673

Howe ER, Simenstad CA (2011) Isotopic determination of food web origins in restoring and ancient estuarine wetlands of the San Francisco Bay and Delta. Estuar Coast 34:597-617

Howe ER, Simenstad CA, Toft JD, Cordell JR, Bollens SM (2014) Macroinvertebrate prey availability and fish diet selectivity in relation to environmental variables in natural and restoring north San Francisco Bay tidal marsh channels. S Francisco Estuar Watershed Sci 12:1-46, http://escholarship.org/uc/item/0p01q99s

Keister JE, Peterson WT (2003) Zonal and seasonal variations in zooplankton community structure off the central Oregon coast, 1998-2000. Prog Oceanogr 57:341-361

Kimmerer WJ, Orsi JJ (1996) Causes of long-term declines in zooplankton in the San Francisco Bay estuary since 1987. In: Hollibaugh JT (ed) San Francisco Bay: the ecosystem. Pacif Div Am Assoc Adv Sci, San Francisco, CA, p 403-424

Kneib RT (1997) The role of tidal marshes in the ecology of estuarine nekton. Oceanogr Mar Biol Annu Rev 35: $163-220$

> Lee CE (2000) Global phylogeography of a cryptic copepod 
species complex and reproductive isolation between genetically proximate 'populations'. Evolution 54:2014-2027

Lopez CB, Cloern JB, Schraga TS, Little AJ, Lucas LV, Thompson JK, Burau JR (2006) Ecological values of shallow-water habitats: implications for the restoration of disturbed ecosystems. Ecosystems 9:422-440

Lougee L, Bollens SM, Avent SR (2002) The effect of haloclines on vertical distribution and migration of zooplankton. J Exp Mar Biol Ecol 278:111-134

> Mac Nally R, Thomson JR, Kimmerer WJ, Feyrer F and others (2010) Analysis of pelagic species decline in the upper San Francisco Estuary using multivariate autoregressive modeling (MAR). Ecol Appl 20:1417-1430

Marques SC, Azeiteiro UM, Marques JC, Neto JM, Pardal MÂ (2006) Zooplankton and ichthyoplankton communities in a temperate estuary: spatial and temporal patterns. J Plankton Res 28:297-312

- Mazumder D, Saintilan N, Williams RJ (2009) Zooplankton inputs and outputs in the saltmarsh at Towra Point, Australia. Wetlands Ecol Manag 17:225-230

McCune B, Mefford MJ (2006) PC-ORD. Multivariate analysis of ecological data, Version 5.10. MjM Software, Gleneden Beach, OR

Meng L, Orsi JJ (1991) Selective predation by larval striped bass on native and introduced copepods. Trans Am Fish Soc 120:187-192

Minello TJ, Able KW, Weinstein MP, Hays CG (2003) Salt marshes as nurseries for nekton: testing hypotheses on density, growth and survival through meta-analysis. Mar Ecol Prog Ser 246:39-59

Moyle PB (2008) The future of fish in response to large-scale change in the San Francisco Estuary, California. Am Fish Soc Symp 64:1-18

Moyle PB, Herbold B, Stevens DE, Miller LW (1992) Life history and status of delta smelt in the Sacramento-San Joaquin estuary, California. Trans Am Fish Soc 121:67-77

Nichols FH, Cloern JE, Luoma SM, Peterson DH (1986) The modification of an estuary. Science 231:567-573

Nobriga ML (2002) Larval delta smelt diet composition and feeding incidence: environmental and ontogenetic influ-

Editorial responsibility: Nikolaos Schizas,

Mayagüez, Puerto Rico, USA ences. Calif Fish Game 88:149-164

Odum WE (1988) Comparative ecology of tidal freshwater and salt marshes. Annu Rev Ecol Syst 19:147-176

Orsi JJ, Walter TC (1991) Pseudodiaptomus forbesi and $P$. marinus (Copepoda: Calanoida), the latest copepod immigrants to California's Sacramento-San Joaquin Estuary. In: Uye SI, Nishida S, Ho JS (eds) Proc 4th Int Conf Copepoda, Karuizawa, Japan, 16-20 September 1990. Bull Plankton Soc Japan Spec Vol:553-562

Purkerson DG, Doblin MA, Bollens SM, Luoma SN, Cutter GA (2003) Selenium in San Francisco Bay zooplankton: potential effects of hydrodynamics and food web interactions. Estuaries 26:956-969

Rollwagen-Bollens G, Penry D (2003) Feeding dynamics of Acartia spp. copepods in a large, temperate estuary (San Francisco Bay, CA). Mar Ecol Prog Ser 257:139-158

> Rollwagen-Bollens G, Penry D, Bollens SM (2006) Vertical distribution of micro- and nanoplankton in the San Francisco Estuary, in relation to hydrography and predators. Aquat Microb Ecol 44:143-163

Rollwagen-Bollens GC, Gifford SM, Bollens SM (2011) The role of protistan microzooplankton in the upper San Francisco Estuary planktonic food web: source or sink? Estuar Coast 34:1026-1038

Soetaert K, Van Rijswijk P (1993) Spatial and temporal patterns of the zooplankton in the Westerschelde estuary. Mar Ecol Prog Ser 97:47-59

Sommer T, Armor C, Baxter R, Breuer R and others (2007) The collapse of pelagic fishes in the upper San Francisco Estuary. Fisheries 32:270-277

Visintainer TA, Bollens SM, Simenstad C (2006) Community composition and diet of fishes as a function of tidal channel geomorphology. Mar Ecol Prog Ser 321:227-243

Whitley SN, Bollens SM (2014) Fish assemblages across a vegetation gradient in a restoring tidal freshwater wetland: diets and potential for resource competition. Environ Biol Fishes 97:659-674

> Zhou S, Jin B, Qin H, Wu J (2009) Spatial distribution of zooplankton in the intertidal marsh creeks of the Yangtze River Estuary, China. Estuar Coast Shelf Sci 85:399-406

Submitted: February 12, 2013; Accepted: July 14, 2014

Proofs received from author(s): September 3, 2014 